\title{
口 OPINIE OBECNYCH I PRZYSZEYCH PACJENTÓW O INTERNECIE JAKO MARKETINGOWYM ŹRÓDLE INFORMACJI O PODMIOCIE LECZNICZYM
}

\author{
OPINIONS OF CURRENT AND FUTURE PATIENTS ABOUT THE INTERNET AS A MARKETING \\ SOURCE OF INFORMATION ON THE MEDICAL ENTITY
}

\author{
Iwona Nowakowska ${ }^{1}$, Sylwia Drzewiecka², Beata Piguła², Renata Rasińska ${ }^{1}$ \\ ${ }^{1}$ Zakład Organizacji i Zarządzania w Opiece Zdrowotnej \\ Uniwersytet Medyczny im. Karola Marcinkowskiego w Poznaniu \\ ${ }^{2}$ Wydział Nauk o Zdrowiu \\ Uniwersytet Medyczny im. Karola Marcinkowskiego w Poznaniu
}

DOI: https://doi.org/10.20883/pielpol.2017.68

\section{STRESZCZENIE}

Wstęp. Marketing usług zdrowotnych to proces polegający na opracowywaniu, komunikowaniu, a także przekazywaniu wartości osobom korzystającym z opieki zdrowotnej. Obejmuje również zarządzanie kontaktami z pacjentami w celu zapewnienia korzyści zarówno dla podmiotu leczniczego, jak i dla pacjenta. Podmioty działalności leczniczej głównie skupiają swoje działania marketingowe i informacyjne w Internecie, który jest powszechnym i najczęściej używanym środkiem komunikacji, wypierającym coraz bardziej tradycyjne środki przekazu komunikacyjnego.

Cel. Poznanie opinii pacjentów obecnych i przyszłych na temat zapotrzebowania i oceny dostępności informacji o ofercie usług zdrowotnych udzielanych przez poszczególne podmioty lecznicze znajdujące się w Internecie, a także określenie grupy osób, które dokonują wyboru wykonawcy usług medycznych, kierując się opiniami o lekarzach zamieszczających informacje o swoich usługach w Internecie.

Materiał i metody. Ankieta została przeprowadzona z wykorzystaniem elektronicznego formularza ankiety udostępnionego w mediach społecznościowych. Swoim zasięgiem objęła 111 respondentów, którzy dobrowolnie i anonimowo wzięli udział w badaniu. Ankieta zawierała 22 autorskie pytania dotyczące korzystania z informacji o dostępnych w Internecie podmiotach leczniczych i usługach zdrowotnych, a także czynników warunkujących wybór danego lekarza bądź podmiotu leczniczego.

Wyniki i wnioski. Internet jest powszechnym źródłem informacji o podmiocie leczniczym w opinii pacjentów obecnych i przyszłych. Pomimo częstego korzystania z Internetu przez pacjentów niewielu z nich wykorzystuje możliwość rejestracji elektronicznej, choć ich liczba stale wzrasta. Pacjenci mają świadomość ryzyka związanego z istnieniem sieci nieprawdziwych informacji na tematy zdrowotne. Najczęściej informacji o jednostkach chorobowych wyszukują osoby młode i w średnim wieku, za najpopularniejsze źródła uznając fora internetowe, blogi i portale medyczne. Pomimo świadomości ryzyka autodiagnozy i samoleczenia pacjenci nadal wykorzystują Internet w tym celu.

SŁOWA KLUCZOWE: marketing usług zdrowotnych, Internet, podmiot leczniczy.

\begin{abstract}
Introduction. Marketing of healthcare services is a process of developing, communicating and passing values to people who make use of healthcare. It also includes managing contacts with patients in order to provide benefits both to the healthcare entity and to the patient. Healthcare entities mainly focus their marketing and information activities on the Internet, which is a common and most frequently used way of communication, increasingly displacing the traditional ones.

Aim. To know the opinions of present and future patients on the needs and assessment of the availability of information about the offer of health services provided by particular healthcare entities on the Internet, as well as to identify the group of people who choose a provider of medical services based on the opinions about doctors who put information about their services on the Internet. Material and methods. The survey was conducted using an electronic questionnaire form shared in social media. It included 111 respondents who voluntarily and anonymously participated in the study. The questionnaire contained 22 author questions regarding the use of information about healthcare entities and serices available on the Internet, as well as the factors determining the choice of the doctor or medical institution.

Results and conclusions. The Internet is a widespread source of information on a healthcare entity in the opinion of present and future patients. Despite the frequent use of the Internet by patients, few of them use the electronic registration option, although this number is steadily increasing. Patients are aware of the risks associated with the existence of a network of false information about the subjects related to health. Information about disease is mostly searched by young and middle-aged people, the most popular sources being online forums, blogs and medical portals. Despite the awareness of the risk of self-diagnosis and self-treatment, patients still continue to use the Internet for this purpose.
\end{abstract}

KEYSWORDS: health marketing service, internet, health clinic. 


\section{Wstęp}

Marketing usług zdrowotnych to proces polegający na opracowywaniu, komunikowaniu, a także przekazywaniu wartości osobom korzystającym z opieki zdrowotnej. Obejmuje również zarządzanie kontaktami z pacjentami w celu zapewnienia korzyści zarówno podmiotowi leczniczemu, jak i pacjentowi. Jest on nie tylko ukierunkowany na przekazywanie niezbędnych informacji o podmiocie działalności leczniczej, ale służy również podwyższaniu świadomości w podejmowaniu decyzji odnośnie własnego zdrowia. Dzięki temu wpływa także na częstsze podejmowanie zachowań prozdrowotnych, przyczyniając się do ogólnego polepszenia stanu zdrowia i samopoczucia. Sprzyja to, cieszącym się coraz większą popularnością, profilaktyce i promocji zdrowia.

Obecnie marketing to coraz silniejsze narzędzie pozyskiwania pacjentów $z$ uwagi na stale rosnącą konkurencję na rynku usług medycznych zarówno w Polsce, jak i poza jej granicami. Podmioty lecznicze głównie swoje działania marketingowe i informacyjne skupiają w Internecie, który jest powszechnym i najczęściej używanym środkiem komunikacji, coraz bardziej wypierającym tradycyjne środki przekazu komunikacyjnego. Odgrywa istotną rolę w budowaniu pozytywnych relacji między podmiotem leczniczym a pacjentem, a także w budowaniu i zwiększaniu świadomości zdrowotnej. Dzięki budowaniu pozytywnej relacji pacjent będzie efektywniej uczestniczył w procesie diagnostyczno-terapeutycznym, co w konsekwencji wywierać będzie pozytywny skutek $w$ procesie jego rekonwalescencji. Coraz częściej obserwuje się wzrost zainteresowania odpłatnymi usługami świadczonymi przez prywatne podmioty działalności leczniczej. Dzięki szerokiemu dostępowi do Internetu oraz możliwości oceny i zaopiniowania podmiotów leczniczych i lekarzy pacjenci mają szanse wyboru najdogodniejszego miejsca realizacji usług zdrowotnych. Preferencje pacjentów zmieniają się, wzrasta świadomość ich praw, co skutkuje koniecznością dostosowania jakości usług zdrowotnych do wymagań pacjentów [1-3].

\section{Cel}

Celem niniejszego opracowania jest poznanie opinii pacjentów obecnych i przyszłych na temat zapotrzebowania i oceny dostępności informacji o ofercie usług zdrowotnych udzielanych przez poszczególne podmioty lecznicze znajdujące się w Internecie, a także określenie grupy osób, które dokonują wyboru wykonawcy usług medycznych, kierując się opiniami o lekarzach zamieszczających informacje o swoich usługach w Internecie.

\section{Materiał i metody}

Ankieta została przeprowadzona z wykorzystaniem elektronicznego formularza udostępnionego w mediach społecznościowych. Dobrowolnie i anonimowo odpowiedzi udzieliło 111 respondentów. Ankieta zawierała 22 autorskie pytania dotyczące korzystania z udostępnionych w Internecie informacji o podmiotach leczniczych i usługach zdrowotnych, a także czynników warunkujących wybór danego lekarza bądź podmiotu leczniczego.

\section{Wyniki}

W badaniu w większości $(78,4 \%)$ wzięły udział kobiety, natomiast wiek respondentów w 71,2\% mieścił się w przedziale 18-25 lat. Ponad połowa badanych to mieszkańcy dużego miasta powyżej 100 tys. mieszkańców (58,6\%), natomiast mieszkańcy wsi stanowili $21,6 \%$. Ankietowani najczęściej szukali informacji na temat podmiotu leczniczego oraz lekarzy, jednak bardziej interesowali się informacjami dotyczącymi konkretnego lekarza niż podmiotu, w którym udziela świadczeń medycznych. Jedynie 7,2\% ankietowanych nigdy nie poszukiwało wiadomości na temat lekarza. Prawie połowa badanych osób zadeklarowała, że sporadycznie (1-5 razy) korzystała $z$ Internetu w celu wyszukania danych na temat lekarza bądź podmiotu leczniczego, natomiast 37,1\% skorzystało z takiej możliwości ponad 10 razy. Pacjenci w większości przypadków interesowali się wizytami w gabinetach prywatnych, jednak usługi refundowane przez NFZ również były w kręgu ich zainteresowań. Wyszukiwanie dotyczyło szerokiego spektrum specjalizacji lekarskich, przy czym największe zainteresowanie skupiło się na specjalizacjach w dziedzinie: ginekologii, stomatologii, chirurgii, dermatologii oraz pediatrii. Osoby zainteresowane usługami zdrowotnymi najczęściej poszukiwały informacji bezpośrednio na stronach internetowych podmiotu $(75,5 \%)$, prawie tyle samo ankietowanych swoje poszukiwania przeprowadzało za pomocą portalu www.znanylekarz. pl $(72,5 \%)$. Wśród podstawowych informacji największą popularnością cieszyły się: adres $(68,3 \%)$, numer telefonu (69,2\%), godziny otwarcia $(71,2 \%)$, cennik (72,1\%). Jednak zdecydowana większość, bo aż 80,8\%, zadeklarowała chęć poznania opinii innych pacjentów na temat danego lekarza bądź podmiotu leczniczego. Najmniejszą popularnością cieszyły się informacje na temat udogodnień dla niepełnosprawnych, udogodnień dla matek z dziećmi, jak również dostępu do miejsc parkingowych oraz programów lojalnościowych lub akcji profilaktycznych. Pomimo dużego zainteresowania opiniami o lekarzach jedynie $14 \%$ badanych zawsze kieruje się opiniami pozyskanymi z Internetu. Z kolei $73,8 \%$ ankietowanych robi to czasami. Mimo coraz większej 
informatyzacji życia i sektora opieki zdrowotnej ponad $50 \%$ osób nie korzystało z możliwości zarejestrowania się online na wizytę; taką formę rejestracji wybrało jedynie $17,1 \%$. Najchętniej pacjenci umawiają się na wizytę telefonicznie (68,5\%). Znikomą popularnością cieszyły się przekazywane pacjentom drogą elektroniczną zaproszenia do udziału $\mathrm{w}$ badaniach profilaktycznych, ponieważ $82 \%$ respondentów nigdy nie skorzystało z propozycji wzięcia udziału w takim badaniu. Wśród osób, które aktywnie odpowiedziały na zaproszenie do udziału w badaniach profilaktycznych, największą popularnością cieszyły się: mammografia, badania krwi oraz pomiar ciśnienia tętniczego. Na pytanie dotyczące weryfikacji znalezionych w Internecie informacji ponad połowa pacjentów $(53,2 \%)$ odpowiedziała, że robi to czasami lub zawsze (27,9\%). Natomiast podczas samej wizyty lekarskiej tylko 12,5\% sprawdza rzetelność porady lekarskiej. Badani potwierdzili, że większe zaufanie wzbudza u nich lekarz, który jest obecny w zasobach Internetu (41,4\%). Oprócz danych wyszukanych w Internecie respondenci kierowali się opiniami rodziny i znajomych (75,\%), a także bliskością podmiotu leczniczego lub gabinetu lekarskiego (58,6\%). Odwiedzając stronę internetową podmiotu świadczącego usługi zdrowotne, ankietowani zwracali uwage nie tylko na funkcjonalność strony, ale również na jej estetykę (55\%). Prawie wszyscy badani $(92,8 \%)$ zadeklarowali, że nie korzystali z konsultacji lekarskich online. W zdecydowanej większości przypadków poszukiwanie informacji okazało się owocne, ponieważ aż 92,2\% osób określiło uzyskane wiadomości jako przydatne w całości lub w części.

\section{Dyskusja}

W wyniku przeprowadzonych badań zauważono, że większość osób korzystających z Internetu wyszukuje informacji najczęściej o lekarzach i opinii o nich, o usługach medycznych, a następnie o podmiotach leczniczych. Otrzymane wyniki dowodzą, że znaczna część badanych odwiedza liczne strony i fora internetowe w celu zdobycia informacji na temat zdrowia i udzielanych przez podmioty lecznicze świadczeń. Istotny jest fakt, że ankietowani odczuwają potrzebę dzielenia się informacjami zdrowotnymi, a także korzystania z informacji zamieszczanych przez innych użytkowników forów internetowych, mając nadzieję na otrzymanie obiektywnych ocen i uwag. Niepokojącym zjawiskiem są sytuacje, w których internauci weryfikują online informacje uzyskane od lekarza, co świadczyć może z jednej strony o braku zaufania do lekarzy, zaś z drugiej - o wyolbrzymionym zaufaniu do informacji zamieszczonych w Internecie. Już około 17\% użytkowników przyznaje, że przynajmniej raz nie zastosowali się do poleceń lekarza, przyjmowania zapisanych leków bądź zaprzestali leczenia ze względu na informacje wyszukane w sieci [4]. Zdarza się również, że pacjenci wybierają konsultację online zamiast tradycyjnej formy konsultacji lekarskiej, co także może wzbudzać niepokój. Ciekawym spostrzeżeniem jest fakt, iż pomimo powszechnego korzystania z Internetu w celu uzyskania wszelkich informacji medycznych niewielu z pacjentów wybiera elektroniczną rejestrację na wizytę. Pacjenci preferują metodę telefoniczną bądź kontakt osobisty, rejestrując się na konsultację. Najczęstszymi użytkownikami stron o profilu zdrowotnym są osoby dobrze wykształcone oraz mieszkające w większych miastach. Co ciekawe, to kobiety częściej wyszukują informacji na temat zdrowia, co może świadczyć, o tym, że to właśnie one są bardziej (od mężczyzn) zainteresowane swoim zdrowiem i w większym stopniu o nie dbają. Osoby starsze prawdopodobnie nie są przekonane do takiej nowoczesnej metody jako źródła informacji o podmiocie leczniczym, gdyż stosunkowo rzadko z niej korzystają [4]. Zapewne wynika to też z tego, że era Internetu pochłonęła przede wszystkim pokolenie osób młodych. Niestety, częste błędy w komunikacji bezpośredniej popełniane przez personel medyczny skłaniają pacjentów do wyszukiwania informacji w sieci, co powoduje, że pacjent samodzielnie się diagnozuje i wykazuje indywidualizm w procesie leczenia. Zaczyna to stanowić poważny problem, który zostaje coraz bardziej dostrzegany, na co dowodem jest powstanie w 2015 roku kampanii „Internet nie leczy” [5, 6]. Mimo zauważalnych problemów z komunikacją na linii pacjent - personel medyczny coraz więcej podmiotów leczniczych korzysta z rozwoju technologii, dając swoim pacjentom możliwość załatwienia wielu spraw bez wychodzenia z domu, za pośrednictwem Internetu (są to m.in.: elektroniczna rejestracja, zamawianie recept online, konsultacje online, odbiór wyników przez Internet, podgląd do historii choroby online). Pacjenci chętnie korzystają z nowoczesnych rozwiązań, oszczędzając przy tym czas, który spędziliby na oczekiwaniu na wizytę czy dojazd do gabinetu [7-12].

Pomimo powszechnego dostępu do internetowych informacji nt. etiologii, patogenezy, leczenia chorób zdecydowana większość internautów (82\%) deklaruje, iż ich zdaniem ryzykowne jest samodzielne leczenie się. Duża grupa Polaków, bo trzech na czterech badanych, zauważa również, że w sieci wypowiadają się osoby, które nie mają odpowiedniej wiedzy i kwalifikacji, aby móc udzielać medycznych porad. Na ten pogląd wpływ może mieć szerząca się moda na prowadzenie różnego rodzaju blogów w celach zarobkowych. Jednymi z wiodących tematów są zdrowie, opieka nad dzieckiem, odchudzanie oraz zdrowy styl życia. Takie blogi często prowadzą np. matki, które są na urlopach macierzyńskich i opisują swoje prywatne doświadcze- 
nia, przy czym nie mają żadnej wiedzy medycznej, nie konsultują tekstów z medykami. Jest to popularne źródło informacji zwłaszcza wśród młodych osób [13, 14]. Popularność tę potwierdzają również przeprowadzone przez Ziuziańskiego i Furmankiewicz badania, w których wśród najpopularniejszych narzędzi autodiagnozy respondenci wymienili m.in. fora internetowe i grupy dyskusyjne (70\%), następnie portale poświęcone zdrowiu $(66 \%)$ oraz encyklopedie internetowe (np. Wikipedia - 55\%) [15, 16]. Inaczej wygląda sytuacja, w której to sami chorzy na daną chorobę udzielają rad na forach innym chorym. Za przydatne i wartościowe treści takie wpisy uważa $58 \%$ ankietowanych, co piąty ankietowany odpowiedział, iż uważa takie wpisy za bardziej przydatne niż porada lekarza. Ten wynik może niepokoić i świadczy o dość niskim zaufaniu do lekarzy, natomiast sporym zaufaniu do osób nieznanych, które mogą inaczej reagować na podobne objawy lub jednostkę chorobową. Zaobserwowano, iż postawę znacznie przychylniejszą do „samoleczenia” reprezentują osoby o niskich dochodach, będące w gorszej sytuacji materialnej [4]. W badaniach Ziuziańskiego i Furmankiewicz respondenci umieścili wiarygodność Internetu na trzecim miejscu, zaraz po lekarzu i książkach medycznych, natomiast przed telewizją i prasą [15, 16]. O ile wiara w porady obcych osób jest dość duża, to w przypadku informacji o lekach zaufanie jest mocno ograniczone. Spośród badanych $80 \%$ osób zadeklarowało niechęć wobec kupowania leków przez Internet, obawiając się braku kontroli nad dokonanym zakupem. Co ciekawe, wszystkie wymienione wyżej kwestie zostały krytyczniej ocenione przez użytkowników Internetu niż przez osoby z niego niekorzystające. Można zauważyć, że osoby korzystające z Internetu mimo podejmowanych aktywności i wyborów mają świadomość ryzyka z nimi związanego. Natomiast osoby niekorzystające z Internetu znacznie częściej deklarowały zaufanie do informacji z różnych portali lub odpowiadały „trudno powiedzieć”. Może to świadczyć o braku świadomości niekontrolowanych wpisów albo zaufaniu do „wszechwiedzącego” Internetu [4]. Pomimo świadomości zagrożeń płynących z autodiagnozy i samoleczenia na podstawie internetowych informacji użytkownicy sieci nadal korzystają z tych źródeł, niekiedy starając się filtrować pozyskane informacje [15].

\section{Wnioski}

1. W opinii pacjentów obecnych i przyszłych Internet jest powszechnym źródłem informacji o podmiocie leczniczym.

2. Pomimo częstego korzystania z Internetu przez pacjentów niewielu z nich korzysta z rejestracji elektronicznej, choć ich liczba systematycznie wzrasta.

3. Pacjenci mają świadomość ryzyka związanego $z$ istnieniem sieci nieprawdziwych informacji na tematy zdrowotne.

4. Najczęściej informacji o chorobach wyszukują osoby młode i w średnim wieku, za najpopularniejsze źródła uznając fora internetowe, blogi i portale medyczne.

5. Pomimo świadomości ryzyka autodiagnozy i samoleczenia pacjenci nadal wykorzystują Internet w tym celu.

\section{Piśmiennictwo}

1. Bratek S, Fedorowski J. Marketing usług zdrowotnych. W: Fedorowski J, Niżankowski R (red.). Ekonomika medycyny. Warszawa: PZWL; 2002. 127.

2. Kotler P, Shalowitz J, Stevens RJ. Marketing strategiczny w opiece zdrowotnej. Warszawa: Wyd. Wolters Kluwer Polska; 2011. 27.

3. Nowotarska-Romaniak B. Marketing usług zdrowotnych. Kraków: Kantor Wydawniczy Zakamycze; 2002. 11, 14-15.

4. Zdrowie online. Komunikat z badań nr 148/2016. Warszawa: CBOS; 2016. 1-19.

5. Ruszyłakampaniaspołeczna,Internetnieleczy”, http://www. rynekzdrowia.pl/Uslugi-medyczne/Ruszyla-kampaniaspoleczna-quot-Internet-nie-leczyquot,155325,8.html (data dostępu: 6.05.2017)

6. Lekarzeostrzegają:internetnieleczy,https://www.termedia. $\mathrm{pl} / \mathrm{mz} /$ Lekarze-ostrzegaja-internet-nieleczy, 19045.html (data dostępu: 6.05.2017).

7. Pacjent plus internet równa się... diagnoza. Ale jaka? (Dostępne w Internecie:) http://www.rynekzdrowia.pl/Uslugimedyczne/Pacjentplus-internet-rowna-sie-diagnoza-Alejaka,116904,8.html (data dostępu: 6.05.2017).

8. $\mathrm{Dr}$ Internet coraz bardziej popularny. Co utrudnia komunikację pomiędzy lekarzem a pacjentem? (Dostępne w Internecie:) http://www.rynekzdrowia.pl/ Nauka/Dr-Internet-coraz-bardziejpopularny-Co-utrudniakomunikacje-pomiedzy-lekarzema-pacjentem,114853,9.html (data dostępu: 6.05.2017).

9. Lekarz, pacjent i... dr Google, https://www.termedia.pl/ poz/Lekarz-pacjent-i-dr-Google,21033.html (data dostępu: 6.05.2017).

10. Prawie połowa Polaków leczy się u doktora Google, https:// www.termedia.pl/mz/Prawie-polowa-Polakow-leczy-sieudoktora-Google,19904.html (data dostępu: 6.05.2017).

11. Coraz chętniej umawiamy się na wizytę lekarską przez Internet, https://www.termedia.pl/mz/Coraz-chetniej-umawiamy-sienawizyte-lekarska-przez-internet,19617.html (data dostępu: 6.05.2017).

12. Jak Polacy korzystają z prywatnej służby zdrowia, https://www.termedia.pl/mz/Jak-Polacy-korzystaja-zprywatnej-sluzbyzdrowia-online,11237.html (data dostępu: 6.05.2017).

13. Ocena jakościowa i ilościowa diet odchudzających stosowanych przez autorki blogów, http://www.phie.pl/pdf/ phe-2012/phe-2012-2-399.pdf (data dostępu: 6.05.2017).

14. Identyfikacja wpływowych jednostek w blogosferze, https://pdfs.semanticscholar.org/c109/bf3bf3e7664a 0289f70a63cd8c3bf9673856.pdf (data dostępu: 6.05.2017).

15. ZiuziańskiP,FurmankiewiczM. Rolainternetuwautodiagnozie i samoleczeniu: szanse i zagrożenia. W: Zieliński Z (red.). Rola informatyki w naukach ekonomicznych i społecznych. Innowacje i implikacje interdyscyplinarne. Kielce: Wyd. Wyższej Szkoły Handlowej; 2014. 65-70. 
16. Furmankiewicz $M$, Sołtysik-Piorunkiewicz, Ziuziański M. Wykorzystanie technologii ICT w społeczeństwie informacyjnym $w$ świetle badań systemów zarządzania wiedzą w e-zdrowiu. W: Białas A (red.). Informatyka w województwie śląskim - innowacyjne trendy rozwoju. Katowice: Instytut Technik Innowacyjnych EMAG; 2015. 37-40.

Artykuł przyjęty do redakcji: 12.12 .2016

Artykuł przyjęty do publikacji: 08.05.2017

Źródło finansowania: Praca nie jest finansowana z żadnego źródła. Konflikt interesów: Autorzy deklarują brak konfliktu interesów.
Adres do korespondencji:

Iwona Nowakowska

ul. Mariana Smoluchowskiego 11

60-179 Poznań

tel.: 618612221

e-mail: iwonanowakowska@op.pl

Zakład Organizacji i Zarządzania w Opiece Zdrowotnej

Uniwersytet Medyczny im. Karola Marcinkowskiego w Poznaniu 